\section{Bright new world}

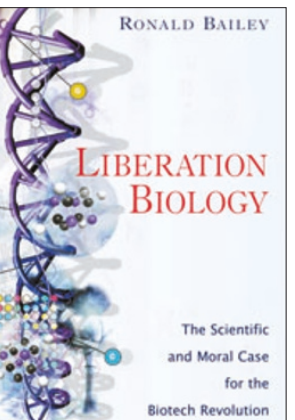

\section{Liberation Biology: The Scientific and Moral Case for the Biotech Revolution}

\author{
by Ronald Bailey \\ Prometheus Books, 2005 \\ 322 pp. hardcover, $\$ 28$ \\ ISBN 1-59102-227-4
}

\section{Reviewed by Jason Borenstein}

In Liberation Biology, Ronald Bailey grapples with many of the key ethical issues raised by our advances in biotech. He seeks to counterbalance the bleak vision of the future, akin to Huxley's Brave New World, predicted by Leon Kass, Francis Fukuyama and other 'bioconservatives.' Bailey's own optimistic view is one where biotech leads humans toward healthier and happier lives, and he unabashedly supports the efforts of scientists to use stem cells, cloning and gene therapy as tools to improve human life.

Early on in the book, Bailey examines whether biotech may provide the means for prolonging human life, presenting extensive results obtained from current antiaging research and discussing the direction that future research may take. He envisions a time, for example, when parents will be able to select longevity genes for their children. While examining the potential benefits of future antiaging therapies, he also strives to answer critics of life extension research. Bailey attributes to the bioethicist Daniel Callahan the argument that many of the social problems we currently experience, such as poverty, war and unemployment, may be intensified if human life expectancy is significantly prolonged. Consequently, it may be unwise to prolong human life substantially before solutions are found for these important social problems. Bailey dismisses what he sees as an overly cautious approach and uncharitably notes that Callahan's recommendation "is just silly." The tone of this response is indicative of the lack of regard the author has for the views of bioethicists.

Bailey offers scathing criticisms of bioethicists throughout the book. He has little patience for the suggestion that we should halt or even extensively regulate biotech research. He frequently chastises those he sees as attempting to interfere with scientific progress by taking advantage of the public's lack of understanding about science and using it to instill fear. He criticizes bioethicists for endorsing paternalistic regulatory policies and suggests that they seem to have a "disdain for patient empowerment." Although his approach is nonpartisan-that is, he attacks the arguments of scholars from both the political left and right-the presentation of his otherwise engaging counterarguments occasionally comes across as being a bit harsh.

Jason Borenstein is at the School of Public Policy, Georgia Institute of

Technology, 685 Cherry Street, Atlanta, Georgia 30332, USA.

e-mail: jason.borenstein@pubpolicy.gatech.edu
Turning his attention toward the promise of genetic research, Bailey acknowledges some of the perils of genetic therapies, discussing among others the death of 18-year-old Jesse Gelsinger, but he asserts that the potential medical benefits of such therapies will far outweigh their hazards. For example, the application of preimplantation genetic diagnosis during in vitro fertilization is largely seen as being an invaluable tool that could prevent the suffering of malformed fetuses and infants. Further, gene therapy, Bailey argues, is one of the scientific avenues whereby liberty and equality could be enhanced. According to Bailey, genetically enhancing our children could "offer them a wider scope of freedom" by providing them with the means to experience better lives.

In agreement with the commonly held view that the promise of stem cell research cannot fully be reached if stem cells from adult sources are the only ones used, Bailey defends the morality of using embryonic stem cells for the purpose of advancing medical science. He argues that there are no compelling reasons to delay embryonic stem cell research and claims that the "moral blockades" created by bioethicists merely interfere with the path of progress. On a related note, Bailey attempts to answer, in a scientific manner, the contentious question of what a human being is. He insists that an embryo is not a person in any significant sense of the term primarily because it does not have a brain. Although his argument is unlikely to sway individuals who believe that the issue must be viewed from a theological perspective, he does effectively capture the hope that stem cell research might alleviate the suffering that millions of people experience.

Regarding the development of chimeras, Bailey maintains that this type of research is largely undertaken for therapeutic purposes and "not the creation of animalized humans or humanized animals." According to the author, critics of the research are overstating the fear that scientists are seeking to design hybrid creatures to serve as human servants. Yet his response to the critics is less than reassuring, considering the increasing frequency with which scientists are splicing together DNA from human and nonhuman sources.

While downplaying the need for public discourse on biotech, Bailey displays much skepticism concerning the ability of the average layperson to comprehend the nature and value of scientific advances. To support his view, he describes the malleable moral 'yuck' reaction that the public has with regard to new technology, including the initial reluctance that the public had toward in vitro fertilization. Further, he claims that the public often fails to recognize the importance of genetically modified crops, a technological advance that he believes may hold the key to alleviating the world hunger problem. Bailey may be right to suggest that the public's understanding of science is lacking. Yet his view is troubling in the sense that it would largely allow scientists to decide which research to perform, without significant regulation.

By attempting to resolve ethical issues associated with aging, stem cell research, cloning and genetic enhancement within the confines of one book, Bailey may be overly ambitious. He is rather dismissive of the need for caution with regard to biotechnological advances; yet, he does seek to engage and answer the moral concerns of the critics of biotech in a sophisticated and honest fashion. Moreover, he provides a hopeful depiction of the future-one where science is the key to obtaining a better life for human beings. 